Ege Tıp Dergisi/Ege Journal of Medicine 2018;57(4):238-240

\title{
Serebral venöz tromboza bağlı agrafisiz aleksi
}

\author{
Alexia without agraphia due to cerebral venous thrombosis \\ Ceren Çetin Akkoç ${ }^{1} \quad$ Figen Gökçay ${ }^{1} \quad$ Dursun Emre Kumral ${ }^{1} \quad$ Funda Çalış $^{2}$ \\ ${ }^{1}$ Ege Üniversitesi Tıp Fakültesi, Nöroloji Anabilim Dalı, İzmir, Türkiye \\ ${ }^{2}$ Ege Üniversitesi Tıp Fakültesi, Fiziksel Tıp ve Rehabilitasyon Anabilim Dalı, İzmir, Türkiye
}

\section{Öz}

Serebral venöz tromboz, dural sinus ve serebral venlerin parsiyel ya da komplet olarak oklüde olduğu serebrovasküler hastalıkların nadir görülen bir alt türüdür. Bu yazıda agrafisiz aleksi ve transkortikal sensoriyel afazi kliniği ile başvurmuş, venöz hemorajik infarktı olan bir sinüs ven trombozu olgusu sunulmuştur. Olgumuz klinik özelliklerinin ender görülmesi, lezyonunun atipik lokalizasyonda olması ve sinüs ven trombozunun farklı kliniklerle karşımıza çıkabileceğinin vurgulanması amacıyla tartışıımıştır.

Anahtar Sözcükler: Serebral venöz tromboz, agrafisiz aleksi.

\begin{abstract}
Cerebral venous thrombosis is a rare subtype of cerebrovascular diseases in which the dural sinuses and cerebral veins are partially or completely occluded. In this article, we present a case of sinus venous thrombosis with venous hemorrhagic infarction referred with alexia without agraphia and transcortical sensory aphasia clinic. Our case is discussed in order to emphasize that the clinical features are rare, the lesion has atypical localization and sinus and venous thrombosis may present with different clinics.
\end{abstract}

Keywords: Cerebral venous thrombosis, alexia without agraphia.

\section{Giriş}

Serebral venöz tromboz (SVT), dural sinus ve serebral venlerin parsiyel ya da komplet olarak oklüde olduğu serebrovasküler hastalıkların nadir görülen bir alt türüdür. Oral kontraseptif ilaç kullanımı, gebelik, puerperium, protein S-C ve antitrombin-3 eksiklikleri, tromboza yatkınlık yaratacak genetik mutasyonlar, polisitemi, bağ dokusu hastalıkları, malignite, enfeksiyonlar, kafa travmaları, inflamatuvar bağırsak hastalığı risk faktörleri arasındadır. Kafa içi basınç artışına bağlı baş ağrısı, bulantı-kusma, papilödem, beyin parankiminin hastalık sürecine katıldığını gösteren nöbetler ve fokal nörolojik defisitler en sık karşılaşılan nörolojik semptomlardır. SVT tanısında klinik olarak tanıyı akılda tutmak önemlidir. Klinik şüphe halinde acil koşullarda kraniyal bilgisayarlı tomografi (BT) görüntülemesi yapılmalıdır. BT ile SVT'den şüphelenildiğinde tanının kesinleştirilmesi için kraniyal manyetik rezonans (MR) ve MR venografi çekilmelidir.

Yazışma Adresi: Ceren Çetin Akkoç

Ege Üniversitesi Tıp Fakültesi Nöroloji Anabilim Dalı İzmir-Türkiye

Makalenin Geliş Tarihi:18.10.2017 Kabul Tarihi: 15.11.2017
SVT tedavisi etiyolojiye yönelik, semptomatik ve antikoagülan tedavidir. Bu yazıda, sol sigmoid sinüs, transvers sinüs ve juguler vende trombüsü olan ve buna bağlı olarak sol temporal bölgede intraparankimal hemorajisi gelişen SVT olgusu sunulmuştur. Olgu, baş ağrısı, agrafisiz aleksi ve transkortikal sensoriyel afazi kliniği ile başvurmuştur. Tanımlanmış klinik tablo ile başvuran olgularda lezyonun, sağ oksipital lob ile sol parietal lob arasındaki bağlantıyı kesintiye uğratacak şekilde sol oksipital lob veya korpus kallozum splenium bölgesinde olması beklenirken, hastamızdaki lezyon lokalizasyonu atipiktir. Olgumuz klinik özellikleri ile nadir rastlanması ve lezyon yerinin atipik olması nedeniyle sunulmuştur.

\section{Olgu Sunumu}

Bilinen hipotiroidi dışında kronik hastalığı olmayan, üniversitede tarih profesörü olarak görev yapan 40 yaşında kadın hasta, akut başlangıçlı şiddetli baş ağrısı ve kelime bulmada güçlük, okuyamama yakınması ile sağlık kurumuna başvurmuş. Yapılan kraniyal MR ve MR venografi görüntülemelerinde sol sigmoid sinüs, transvers sinüs ve juguler vende trombüs ve buna bağlı olarak sol temporal bölgede intraparankimal hemorajisi saptanmış (Şekil-1a,b). 

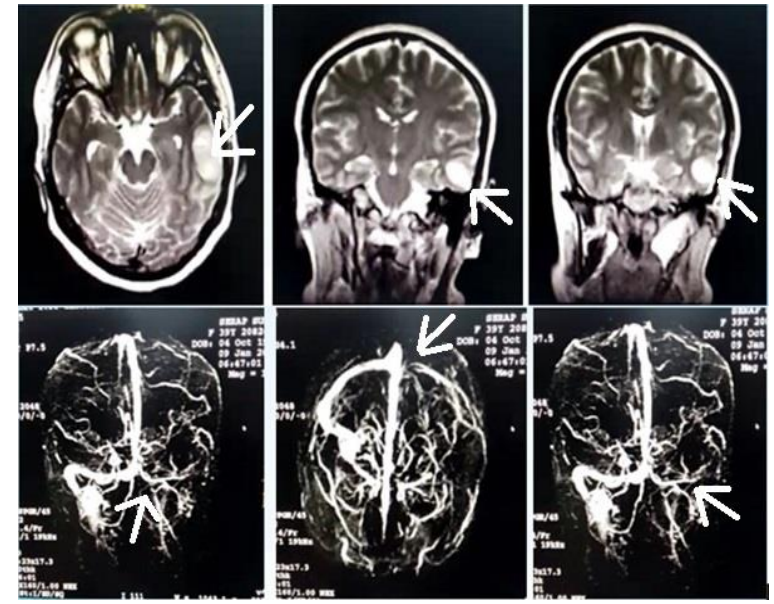

Şekil-1. a. Başvuru sırasında çekilen kraniyal MRG. Sol temporal bölgede intraparankimal hemoraji izlenmektedir. b. Başvuru sırasında çekilen kraniyal MR venografi. Sol sigmoid sinüs, transvers sinüs ve sol juguler vende trombüs izlenmektedir.

SVT tanısıyla enoksaparin sodyum $60 \quad \mathrm{mg} \quad 2 \times 1$ başlanarak ileri tetkik ve tedavi amacıyla kliniğimize gönderilmiş. Baş ağrısı başlangıcından 40 gün önce sezaryen ile doğum yaparak sağlıklı bir erkek bebek dünyaya getirdiği öğrenilen hastanın operasyon sonrasında ve lohusalık döneminde herhangi bir yakınması olmamış. Nörolojik muayenesinde, bilincinin açık, basit emirlere koopere olduğu, kompleks emirleri yerine getiremediği ve kelime bulmakta güçlük çektiği saptandı. Tekrarlaması ve yazması normaldi, fakat okuması ve okuduğunu anlaması bozuktu. Kafa içi basınç artışı sendromu (KIBAS) bulgusu saptanmayan olguda motor-duysal lateralizan bulgu da yoktu. Sağ el dominansı mevcuttu. Mevcut muayene bulguları, transkortikal sensoriyel afazi ve agrafisiz aleksi olarak yorumlandı. Etiyolojiye yönelik yapılan tetkiklerinde herediter trombofili saptanmadı. Vaskülit belirteçlerinde antinükleer antikor (ANA) sentromerik $1 / 5120$ pozitif saptanması nedeniyle yapılan romatoloji konsültasyonu sonucu hastaya mikst tip bağ dokusu hastalığı tanısı koyularak hidroksiklorokin sülfat $200 \mathrm{mg}$ 1x1 başlandı. Etiyolojide postpartum dönem ve olası vaskülitik süreçler sorumlu tutularak antikoagülan tedavisi varfarin olarak düzenlendi. Kontrol kraniyal görüntülemelerinde hemorajisi gerileyen ve taburcu edilen hastanın takiplerinde nörolojik bulgularında belirgin düzelme izlendi. Kontrol nörolojik muayenesinde kompleks emirlere koopere olduğu, doğru kelimeleri rahatlıkla bulduğu görüldü. Hastanın slayt eşliğinde akademik ortamda ders verebildiği öğrenildi.

Hastadan tıbbi verilerin yayımlanacağına ilişkin yazılı onam belgesi alındı.

\section{Tartışma}

Serebral venöz tromboz, seyrek görülen ve farklı klinik tablolarla ortaya çıkabilen bir serebrovasküler hastalıktır. Genç ve doğurganlık çağındaki kadınlarda daha sık görülmektedir. Olgumuz da bununla uyumlu olarak doğurganlık çağında bir kadındı. Klinik trombüsün yerine ve oluşma hızına bağlı olarak ortaya çıkar. En yaygın semptom baş ağrısıdır (\%40). Nöbet (\%27), fokal nörolojik defisit (\%5), papilödem (\%30-80), izole intrakraniyal hipertansiyon, afazi, ihmal, görme alanı defekti gelişebilir $(1,2)$. Klinik olarak iskemik ya da hemorajik inme, beyin apsesi, tümör, ensefalopati, idiyopatik intrakraniyal hipertansiyon ve migren gibi çok farklı nörolojik hastalıkları taklit edebilir. Olgumuzda klinik olarak baş ağrısı ve buna ek olarak transkortikal sensoriyel afazi ve agrafisiz aleksi kliniği mevcuttu. Pür aleksi ya da agrafisiz aleksi, okuma bozukluğu (aleksi) dışında, yazma dahil diğer tüm lisan fonksiyonlarının normal sınırlarda olduğu ender görülen bir klinik tablodur (3). En sık serebrovasküler hastalığa bağlı gelişir. Daha nadir olarak multipl skleroz, travma, tümör, ensefalit, kavernom, arteriovenöz malformasyona bağlı gelişen olgular bildirilmiştir. Bu olgularda en sık rastlanan lezyon lokalizasyonu sağ oksipital lob ile sol parietal lob arasındaki bağlantıyı kesintiye uğratacak, sol oksipital lob veya korpus kallozum splenium bölgesidir. Olgumuzda agrafisiz aleksi kliniği mevcuttur, fakat lezyon atipik lokalizasyondadır. Çoğu olguda splenium tutulumu bildirilmekle birlikte, hastamızda splenium tutulumu saptanmamıştır. Yaptığımı literatür taramalarında temporal bölge lokalizasyonunda lezyonu olup, tanımlanmış klinik tablo ile başvuran olguya rastlanmamıştır. Olgumuz lezyon yerinin atipik olması nedeniyle sunulmuş ve tartışılmıştır. Yeni bir lokalizasyon olarak temporal bölge lezyonlarının da agrafisiz aleksi kliniği ile başvurabileceğine dikkat çekilmek istenmiştir.

SVT etiyolojisinde; gebelik, postpartum dönem, oral kontraseptif kullanımı, koagülopatiler, intrakraniyal enfeksiyonlar, kraniyal tümörler, kafa travmaları, lomber ponksiyon, spinal anestezi, malignite, bağ dokusu hastalıkları, Behçet hastalığı, inflamatuvar bağırsak hastalığı, sarkoidoz, parenteral infüzyonlar ve çeşitli ilaçlar tanımlanmaktadır $(4,5)$. Olgumuzda olası etiyolojik faktör olarak, ön planda postpartum dönem ve ayrımlaşmamış mikst bağ dokusu hastalığı düşünüldü. SVT'de en sık superior sagittal sinüs (\%70-80) etkilenir, sonrasında transvers, sigmoid ve daha az oranda kavernöz sinüs tutulumu görülür. Vakaların üçte birinde birden fazla sinüste etkilenme olur $(6,7)$. Olgumuzda da birden fazla sinüste trombüs saptandı. SVT tedavisi etiyolojiye yönelik, semptomatik ve antikoagülan tedavidir (8). Olgumuzda düşük molekül ağırlıklı heparin ve sonrasında varfarin antikoagülan tedavi olarak uygulandı. Serebral venöz trombozların önemli bir bölümü geniş anastomoz ve kollateral dolaşımın varlığı nedeniyle arteriyel inme ile karşılaştırıldığında iyi seyirlidir (9). Olgumuz izlemde klinik olarak iyi seyretti, şikayetleri tama yakın düzeldi. 
Sonuç olarak, SVT çok çeşitli nörolojik tablolarla ortaya çıkabilir. Yeni başlayan veya karakter değiştiren baş ağrısı ve fokal nörolojik bulguları olan hastalarda SVT ön tanısı klinik olarak akla gelmeli, klinik şüphe halinde hızlı bir şekilde radyolojik araştırmalar yapılmalı ve tedaviye başlanmalıdır.

\section{Kaynaklar}

1. Allroggen H, Abbott RJ. Cerebral venous sinus thrombosis. Postgrad Med J 2000;76(891):12-5.

2. Kimber J. Cerebral venous sinus thrombosis. QJM 2002;95(3):137-42.

3. Rim HT, Jun HS, Ahn JH, et al. Clinical aspects of cerebral venous thrombosis: Experiences in two institutions. J Cerebrovasc Endovasc Neurosurg 2016;18(3):185-93.

4. Partziguian T, Camerlingo M, Casto L, et al. Cerebral venous thrombosis in young adults. Ital J Neurol Sci 1996;17(6):419-22.

5. Starrfelt R, Shallice T. What's in a name? The characterization of pure alexia. Cogn Neuropsychol 2014;31(5-6):367-77.

6. Ferro JM, Canhão P, Stam J, et al. Prognosis of cerebral vein and dural sinus thrombosis: Results of the international study on cerebral vein and dural sinus thrombosis (ISCVT). Stroke 2004;35(3):664-70.

7. Ehtisham A, Stern BJ. Cerebral venous thrombosis: A review. Neurologist 2006;12(1):32-8.

8. Einhaupl K, Stam J, Bousser MG, et al. EFNS guideline on the treatment of cerebral venous and sinus thrombosis in adult patients. Eur J Neurol 2010;17(10):1229-35.

9. Dentali F, Gianni M, Crowther MA, Ageno W. Natural history of cerebral vein thrombosis: A systematic review. Blood 2006;108(4):1129-34. 